\title{
norden
}

Nordisk Råd

Ved Stranden 18

DK-1061 København K

www.norden.org

NORDISKE ARBEJDSPAPIRER NORDIC WORKING PAPERS

\section{Effekten af budgetnedskæringer i NMR}

Analyse af Nordisk Ministerråds budget 2008-2016 og Nordisk Råds rolle i budgetprocessen

Ane Kofod Petersen, Kofod Consult

http://dx.doi.org/10.6027/NA2016-909

NA2016:909

ISSN 2311-0562

Dette arbejdspapir er udgivet med finansiel støtte fra

Nordisk Råd. Indholdet i arbejdspapiret afspejler

dog ikke nødvendigvis Nordisk Råds synspunkter,

meninger, holdninger eller anbefalinger. 



\section{nordon}

Nordisk Råd

Effekten af budgetnedskæringer i Nordisk Ministerråd Analyse af Nordisk Ministerråds budget 2008-2016 og Nordisk Råds rolle i budgetprocessen

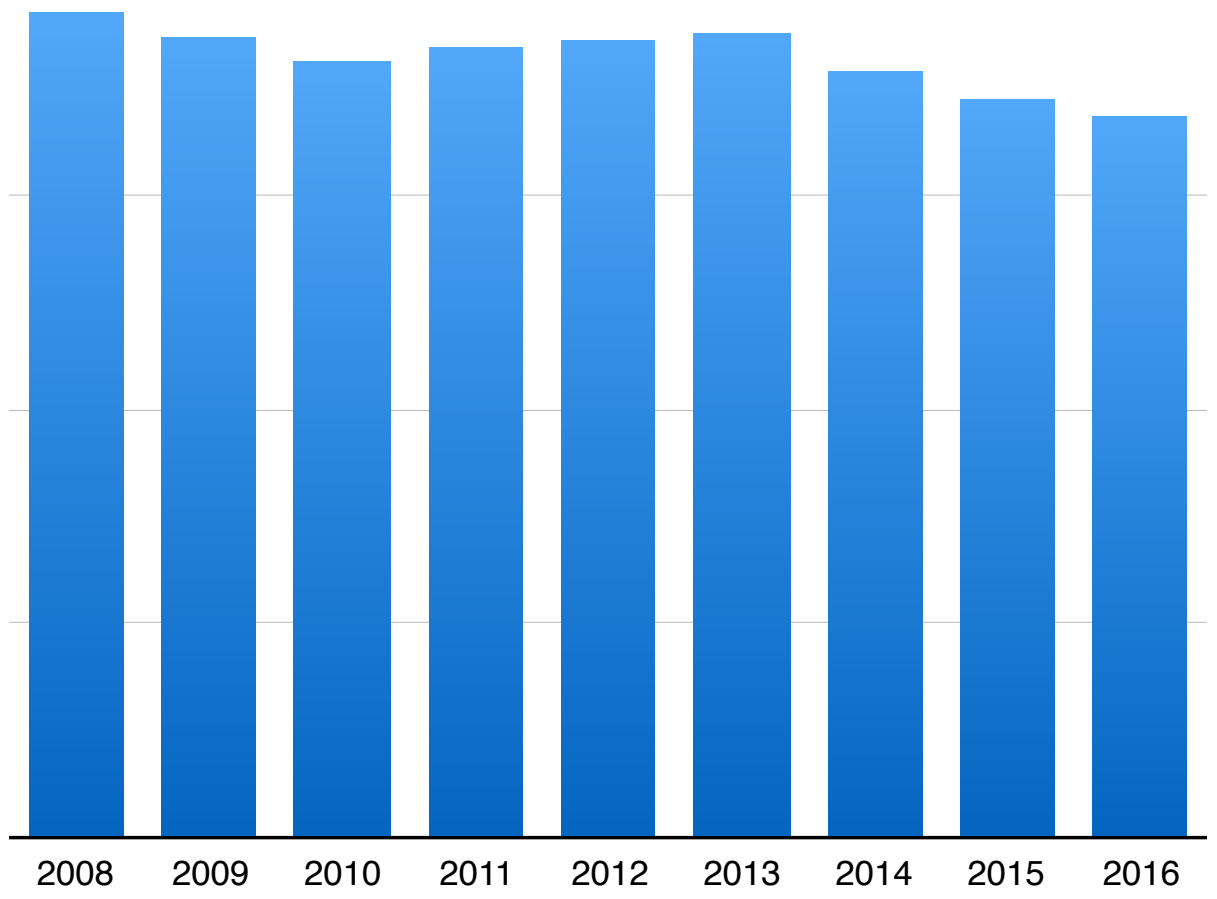

Kofod Consult, 24. maj 2016 
$\begin{array}{ll}\text { Sammenfatning } & 3\end{array}$

$\begin{array}{ll}\text { Indledning } & 4\end{array}$

Analyse af Nordisk Ministerråds budget 2008-2016 5

Etablering af de centrale puljer i Nordisk Ministerråds budget $\quad 5$

$\begin{array}{ll}\text { Nedskæringer i Nordisk Ministerråds budget } & 6\end{array}$

$\begin{array}{ll}\text { Forskydninger mellem budgetkategorier } & 8\end{array}$

Konsekvenser af omprioriteringer og nedskæringer 9

$\begin{array}{ll}\text { Evalueringer af de centrale puljer i budgettet } & 10\end{array}$

$\begin{array}{ll}\text { Interviewpersoner om de centrale puljer } & 10\end{array}$

Interviewpersoner om nedskæringer $\quad 11$

Nordisk Råd og Nordisk Ministerråds budgetproces 13

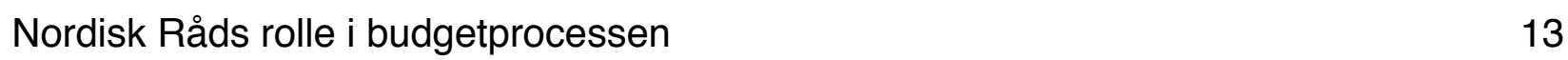

Nordisk Råds input til budgetprocessen 2008-2016 14

Nordisk Råds indflydelse på Nordisk Ministerråds budget $\quad 14$

Interviewpersoner om Nordisk Råds rolle i budgetprocessen $\quad 15$

En styrket rolle for Nordisk Råd i budgetprocessen? 16

$\begin{array}{ll}\text { Konklusion og anbefalinger } & 16\end{array}$

Bilag 1: Interviewspørgsmål 18

Bilag 2: Interviewede personer og organisationer 19

Bilag 3: Anvendte materialer 20

Bilag 4: Liste over anvendte forkortelser 21 


\section{Sammenfatning}

Nordisk Ministerråd har i årene 2008-2016 gennemført forskellige ændringer i sit budget. Dels er der foretaget omprioriteringer af midlerne med henblik på at etablere centrale puljer, dels er den samlede ramme for Ministerrådets budget blevet reduceret.

Omprioriteringerne af budgetmidlerne har sammen med nedskæringerne i budgetårene 2014-2016 medført, at der er sket forskydninger mellem projektmidler og midler til programmer og institutioner, blandt andet er flere af Ministerrådenes puljer til projekter blevet reduceret markant.

ÆEndringerne i budgettet har samtidigt ført til en øget fokusering og prioritering af Ministerrådenes aktiviter og en skærpet opmærksomhed på styringen af projekter og på mulighederne for at tiltrække finansiering til prioriterede indsatser. Globaliseringsinitiativet, som blev lanceret i 2007 , førte endvidere til større synlighed af det nordiske samarbejde og etablering af nye samarbejdsformer.

Nordisk Råd har et ønske om at øge sin indflydelse på Ministerrådets budget. I den nuværende tilrettelæggelse af budgetprocessen er Rådets rolle i Ministerrådets budgetproces dog først og fremmest karakteriseret ved en reaktiv tilgang. Det vil sige, at Rådet reagerer på projektforslaget fra Nordisk Ministerråds Generalsekretær fremfor at proaktivt komme med forslag til prioriteringer tidligere i processen. Nordisk Råds konkrete forslag til budgettet bliver i et vist omfang implementeret i det færdige budget, men udgør mindre end 1\% af budgettet. Nordisk Råd kunne formentlig få større indflydelse på budgettet, hvis man agerede mere proaktivt.

\section{Anbefalinger}

På baggrund af analysen af Nordisk Råds rolle i Nordisk Ministerråds budgetproces, er en række anbefalinger udarbejdet:

1. Nordisk Råd bør have en mere proaktiv tilgang til budgetprocessen.

2. Nordisk Råds udvalg og partigrupper bør drøfte prioriteringerne og udarbejde forslag til Præsidiets drøftelse med Ministerrådet, før budgetanvisningerne udarbejdes.

3. Nordisk Råd bør overveje forslag til finansiering af forslag i form af omprioriteringer i budgettet.

4. Nordisk Råd bør i visse tilfælde udarbejde en udredning eller andet baggrundsmateriale for at støtte sine forslag.

5. Nordisk Råds udvalg bør have en aktiv rolle i behandlingen af Generalsekretærens budgetforslag for de tilhørende sektorer.

6. Nordisk Råd bør overveje at opdele sine forslag til konkrete og mere strukturelle forslag.

7. Nordisk Råd bør have en løbende dialog med Ministerrådet om sine forslag og ønsker til prioriteringer.

8. Nordisk Råd og Nordisk Ministerråd bør ved eventuelle fremtidige nedskæringer se på mulighederne for at foretage prioriterede nedskæringer på de forskellige Ministerråds områder fremfor pro rata nedskæringer.

9. Nordisk Råd bør overveje at styrke Sekretariatets kapacitet i forhold til budgetarbejdet, særligt i forhold til udarbejdelse af baggrundsmateriale (anbefaling 4) og udvalgenes rolle i budgetarbejdet (anbefaling 5). 


\section{Indledning}

Nordisk Råds Kontrolkomité ønsker at få belyst, hvordan det nordiske samarbejde er blevet påvirket af omprioriteringerne siden budget 2008 og nedskæringerne siden budget 2014 i Nordisk Ministerråds budget. Denne rapport analyserer budgetændringerne og ser på, om det vil være muligt at forbedre budgetprocessen, særligt med henblik på at styrke Nordisk Råds rolle i processen. Rapporten er udarbejdet med udgangspunkt i budgetdata, dokumenter fra de årlige budgetforhandlinger mellem Nordisk Råd og Nordisk Ministerråd, evalueringer af Globaliseringsinitiativet, skriftlige interviews af ledelsen af udvalgte nordiske institutioner og samarbejdsorganer, Nordisk Ministerråds Sekretariat og udvalgte medlemmer af Nordisk Råd samt et møde med Nordisk Råds Sekretariat.

\section{Omprioriteringer og reduktioner i Nordisk Ministerråds budget 2008-2016}

Siden budget 2008 er der foretaget en række omprioriteringer og nedskæringer i Nordisk Ministerråds budget. I budgetterne for 2008-2010 blev Ministerrådenes budgetter reduceret i forskellig grad for at frigøre midler til Globaliseringsinitiativet, som var blevet lanceret af de nordiske landes statsministre i 2007. Den centrale pulje, som herved blev etableret, blev videreført med fokus på Grøn Vækst initiativer og Holdbar Nordisk Velfærd i budgetterne for 2011-2012, og blev fra og med budget 2013 omdannet til Prioriteringsbudgettet. I årene 2014-2016 blev den samlede budgetramme for Nordisk Ministerråd reduceret med 5\% i budget 2014, 2\% i budget 2015 og $1 \%$ i budget 2016 .

\section{Modernisering og reform af budgetprocessen}

Nordisk Ministerråd igangsatte i 2014 et moderniserings- og reformarbejde. Dette arbejde omfatter en række tiltag for at styrke det nordiske budget som styrings- og prioriteringsværktøj.

I den forbindelse er opstillingen af Ministerrådets budget ændret, så præsentationen af de enkelte budgetposter er mere fokuseret og transparent. Disse tiltag skal give blandt andre Nordisk Råd bedre mulighed for indsigt i anvendelsen af Ministerrådets midler og bidrage til bedre styring og prioritering i Ministerrådet, for eksempel med hensyn til anvendelse af projektmidler. Som del af Ministerrådets moderningsarbejde indgår også en tættere dialog med Nordisk Råd om budgettet, hvor der foreslås indført et møde mellem Råd og Ministerråd tidligere i budgetprocessen.

Nordisk Råd har sideløbende hermed også igangsat et moderniseringsarbejde, som indebærer en øget fokus på budgetarbejdet i Nordisk Råds Præsidium samt skridt i retning af en ændret budgetproces med henblik på at sikre tidligere inddragelse af Rådet i budgetprocessen. 


\section{Analyse af Nordisk Ministerråds budget 2008-2016}

Udviklingen i Nordisk Ministerråds budget i 2008-2016 har tre væsentlige træk:

- Etablering af centrale puljer til Globaliseringsinitiativer henholdsvis Prioriteringsbudgettet på 7-8 \% af Ministerrådets budget.

- Nedskæringer i den samlede ramme for Ministerrådets budget med i alt $9 \%$, målt i faste priser og DKK.

- Forskydning mellem andelen af projektmidler og midler til mere permanente aktiviteter i Ministerrådets budget.

\section{Etablering af de centrale puljer i Nordisk Ministerråds budget}

Globaliseringsinitiativet blev lanceret af de nordisk landes statsministre i 2007 med henblik på at udvikle den nordiske model, øge konkurrencevnen og skabe større synlighed for Norden som en foregangsregion. Til dette arbejde blev der i budget 2008 afsat 61 millioner DKK (årets priser), svarende til 6,8\% af Nordisk Ministerråds samlede budget. Puljen var finansieret af dels et engangsløft af den samlede budgetramme på 35 millioner DKK, dels en omprioritering af budgettet, som blev finansieret ved en pro rata reduktion på $2 \%$ at rammerne for Ministerrådenes budgetter. I budgetterne for 2009 og 2010 blev puljen til Globaliseringsinitiativet finansieret med pro rata reduktioner af Ministerrådenes rammer. I budget 2009 var reduktionerne henholdsvis $2 \%$ og 5\%, som blev udmøntet forskelligt på de enkelte Ministerråd. Dog var reduktionen på NMR Fællesaktiviteter 10\%. I budget 2010 var reduktionen 1,3\%.

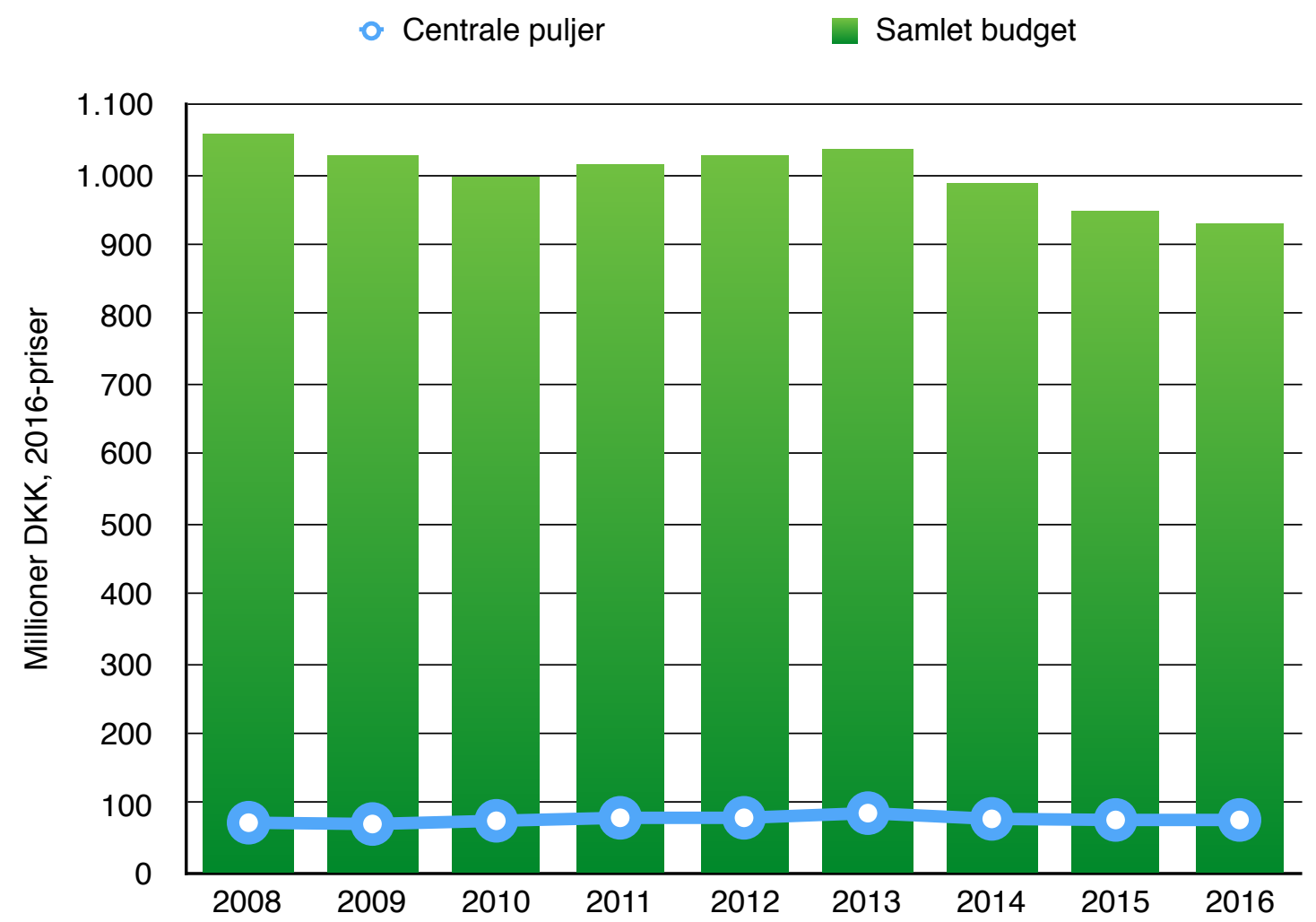

Diagram 1: Centrale puljer (Globalisering, Grøn Vækst/Holdbar Nordisk Velfærd og Prioriteringsbudgettet) som del at Nordisk Ministerråds samlede budget 2008-2016, 2016-priser. 
De tilsyneladende forøgelser af det samlede budget i 2011, 2012 og 2013 skyldes udsving mellem landenes valutakurser, idet institutionernes budgetter er i værtslandets valuta.

Fokuseringen af Globaliseringsarbejdet på Grøn Vækst og Holdbar Nordisk Velfærd fra budget 2011, og Prioriteringsbudgettet, som blev lanceret i budget 2013, med et samlet budget på 81 millioner DKK (årets priser), medførte i sig selv ingen ændringer i Ministerrådenes rammer, idet de blev finansieret af den allerede afsatte ramme for Globaliseringsinitiativet. Med

Prioriteringsbudgettet blev den hidtidige Formandskabspulje under Samarbejdsministrene, som i budget 2012 udgjorde 6 millioner DKK, afskaffet, og 20 millioner DKK af de i alt 81 millioner DKK i Prioriteringsbudgettet afsat til formandskabsinitiativer.

De centrale puljer i budgettet har som nævnt udgjort 7-8\% af budgettet i perioden, og er i budget 2016 ca. $6 \%$ større end i budget 2008, målt i 2016-priser. Puljerne udgjorde 6,8\% af budget 2008 og $8,2 \%$ i budget 2016, inklusive den hidtidige Formandskabspulje.

\section{Nedskæringer i Nordisk Ministerråds budget}

I 2016-priser udgjorde Nordisk Ministerråds budget i 20081.059 millioner DKK, mens det i 2016 er 928 millioner DKK. Der er i perioden således sket en reduktion i Nordisk Ministerråds samlede budget med i alt $12 \%$. Ses der imidlertid bort fra, at budgetrammen for 2008 var forhøjet med 35 millioner DKK (årets priser) som følge af det ekstraordinære engangsløft til Globaliseringsinitiativet, udgør reduktionen af det samlede budget 9\%. I årene 2008-2013 var budgettet på nogenlunde uændret niveau på cirka 1 milliard DKK (2016-priser), igen bortset fra det ekstraordinære engangsløft i budget 2008. I årene 2014-2016 blev rammen reduceret med i alt 7,8\% i forhold til budget 2013: 5\% i 2014, 2\% i 2015 og 1\% i 2016.

Alle Ministerråd har været berørt af nedskæringer af budgetrammen i perioden 2008-2016 som følge af dels omprioriteringer indenfor budgettet, dels reduktion af den samlede ramme for Nordisk Ministerråds budget. Det skal dog understreges, at en egentlig sammenligning af budgetudviklingen for de enkelte Ministerråd over hele perioden vanskeliggøres af, at visse budgetposter i perioden er blevet flyttet fra et Ministerråd til et andet. Ligeledes skal det bemærkes, at for de Ministerråd, som har institutioner beliggende i andre nordiske lande end Danmark, kan udsvingene i budgetterne opgjort i DKK synes større, end de faktisk har været, idet institutionernes budgetter opgøres i værtslandets valuta. Med disse forbehold ses der i det følgende på nogle eksempler på udviklingen i bugettet med henblik på også at belyse betydningen af de centrale puljer nedenfor i Diagram 2. Budget 2009 var det første, hvor projektmidlerne under Globaliseringsinitiativet var fordelt på Ministerrådene, hvorfor sammenligningerne tager udgangspunkt i dette års budget fremfor i budgettet for 2008.

Ved sammenligning mellem budgetterne for 2009 og 2016 er de største nedskæringer sket på Samarbejdsministrenes (MR-SAM), Ministrene for Uddannelse og Forskning (MR-U) samt Socialministrenes (MR-S) områder, og de mindste på Ministrene for Erhvervs-, Energi- og Regionalpolitik's (MR-NER) område.

På MR-SAMs område er der i årene 2009-2016 sket en reduktion på 21\% i 2016-priser, herunder er budgettet til internationalt samarbejde blevet reduceret med $37 \%$. Dette inkluderer dog overflytning af institutionen Nordisk Projekteksportfond (NOPEF), som budgetmæssigt blev flyttet til MR-NER i 2015. Hvis der korrigeres for denne ændring, udgør reduktionen af budgettet for 
internationalt samarbejde i perioden $21 \%$ fra budget 2009 til budget 2016 . Fratrækkes budgettet til NOPEF MR-SAMs samlede budget, udgør reduktionen fra budget 2009 til budget 2016 13\%.

I 2016-priser og DKK blev MR-U's budget fra 2009 til budget 2016 reduceret med knap 13\%, mens MR-S's budget blev reduceret med $12 \%$. Under begge Ministerråd hører institutioner, som ligger i andre nordiske lande end Danmark. De tilsyneladende relativt større reduktioner på de to områder afspejler derfor også udsving i valutakurser, idet institutionernes budgetter opgøres i værtslandets valuta. Især for institutionerne i Norge, herunder NordForsk, har dette betydning, da forholdet mellem NOK og DKK er ændret væsentligt fra 2009 til 2016. På MR-S's område blev det endvidere i 2013 besluttet af MR-SAM at nedlægge Nordic School of Public Health (NHV) med virkning fra 1. januar 2015. Det skal bemærkes, at NHV ikke var finansieret af det nordiske budget, men direkte af landene, og derfor ikke indgik i rammen for MR-S.

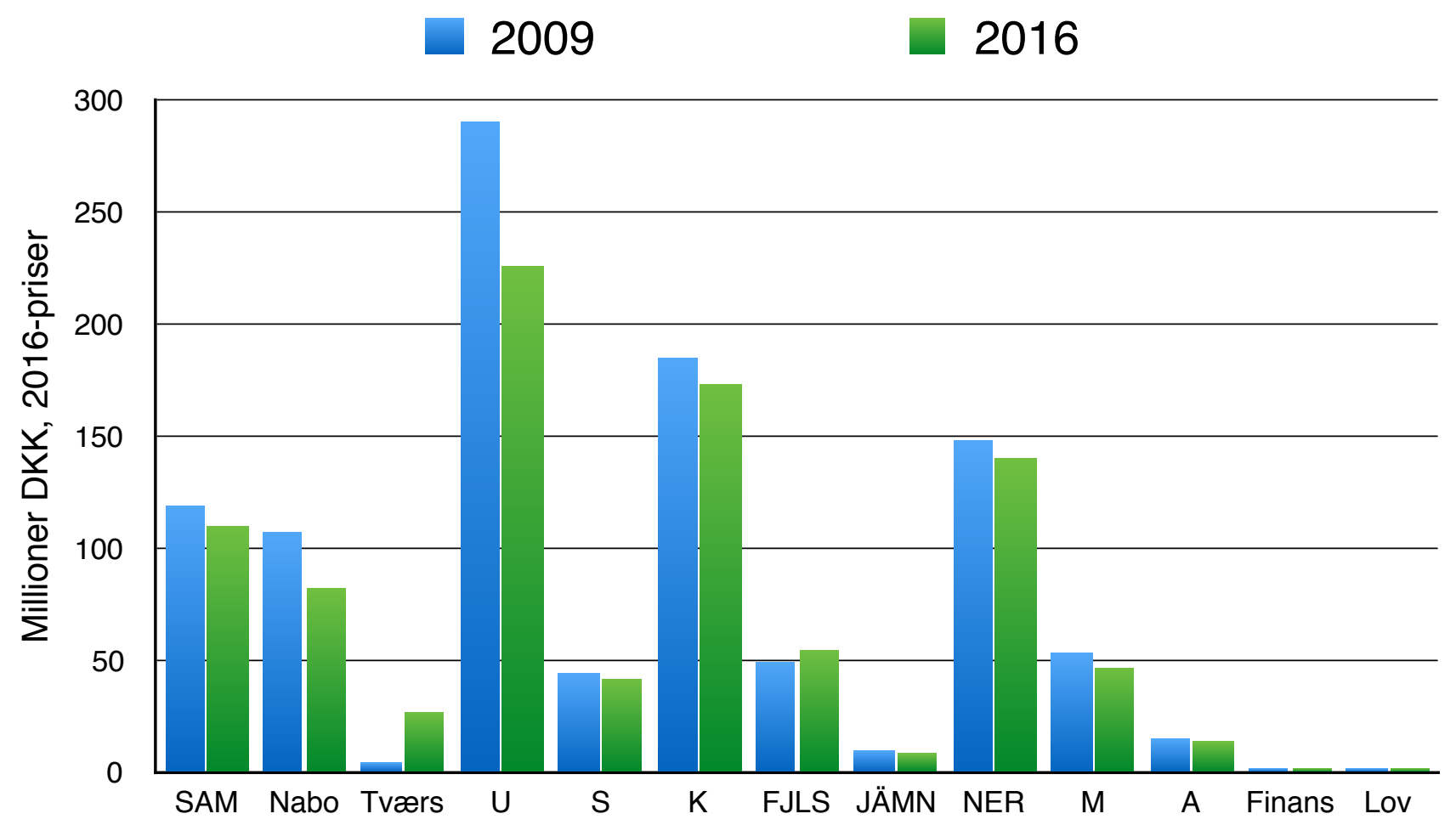

Diagram 2: Budget per Ministerråd tillagt projekter fra de centrale puljer, 2009 og 2016, begge i 2016priser. For projekter, som involverer to Ministerråd, er budgettet fordelt ligeligt på de to Ministerråd. Projekter, som involverer tre eller flere Ministerråd er inkluderet i kategorien tværsektorielle projekter: 'Tværs'. 'Nabo' er budgettet for internationalt samarbejde.

Diagram 2 viser størrelsen af Ministerrådenes budgetter fra 2009 til 2016 i 2016-priser tillagt projekter under de centrale puljer. Forskellen mellem budget 2009 og budget 2016 ser derfor anderledes ud end i ovennævnte tal for budgetreduktionerne. På MR-U's område var der i budget 2009 tre større projekter under Globaliseringsinitiativet: "Nordisk Topforskning", "Plan for fremme af højere uddannelse i Norden", "Projektplan for god oplæring af unge og voksne" samt "NORIA" (fælles med MR-NER) med et samlet budget på over 35 millioner DKK i 2016-priser. I budget 2016 er der kun to mindre projekter under Prioriteringspuljen på MR-U's område: "Forskerudbytte mellem de nordiske udenrigspolitiske institutter" og "Velfærd" (fælles med MR- 
NER). Derimod havde MR-S i budget 2009 ingen projekter under Globaliseringsinitiativet, mens der i Prioriteringsbudgettet i budget 2016 er afsat 3 millioner DKK til projektet "Velfærdsvagten". På MR-SAMs område er der i budget 2016 etableret to projekter under Prioriteringspuljen, som er relateret til Nordisk Ministerråds internationale samarbejde: "Politiske initiativer i nærområderne" med et budget på 3,4 millioner DKK og "Profilering og positionering" med et budget på 10,2 millioner DKK. Sidstnævnte projekt er en opfølgning på Samarbejdsministrenes strategi for international profilering og positionering af Norden, som blev vedtaget i 2014.

\section{Forskydninger mellem budgetkategorier}

Budgetposterne i Nordisk Ministerråds budget er opdelt på forskellige kategorier: 1) Projektmidler, 2) Programlignende aktiviteter inklusive samarbejdsorganer, rene programmer, støtteordninger og arbejdsgrupper, 3) Institutioner/virksomheder samt 4) Organisationsbidrag. Budgetkategorierne blev justeret i budget 2011, så udover på budgetpostniveau er det ikke muligt at foretage direkte sammenligninger gennem hele perioden for budgetkategorierne 1 og 2.

For at sammenligne udviklingen i de fire projektkategorier over tid er der foretaget en beregning for budgetårene 2011-2016, hvor projekterne under de centrale puljer er taget ud af projektkategori 1 og 2. Denne beregning danner baggrund for de sammenligninger af udviklingen indenfor hver budgetkategori, der er nævnt i dette afsnit.

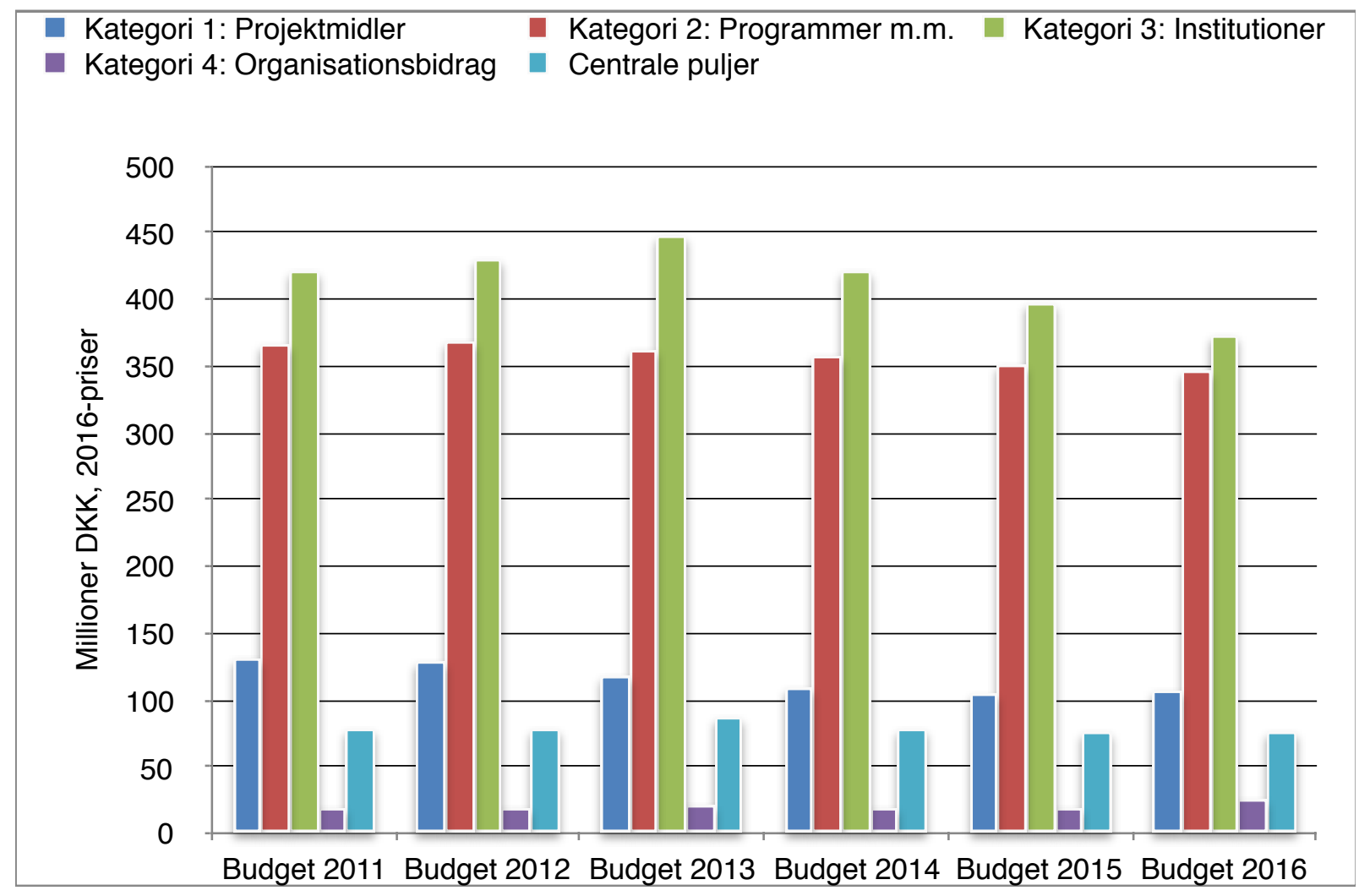

Diagram 3: Nordisk Ministerråds budget 2011-2016 fordelt på budgetkategorier samt centrale puljer, 2016-priser.

Fra budget 2011 til budget 2016 skete der en reduktion af projektmidlerne i Budgetkategori 1 med 18\% i 2016-priser. I budget 2011 udgjorde projektmidler 12,9\% af Ministerrådets samlede budget 
(uden centrale puljer), mens andelen i budget 2016 var reduceret til 11,6\% af budgettet. Over hele perioden 2008 til 2016 er der eksempelvis sket reduktioner med mere end 50\% for projektmidler under jordbrug, skovbrug og social/sundhed.

Programlignende aktiviteter m.v. i Budgetkategori 2 er ligeledes reduceret, dog kun med 5\% fra budget 2011 til budget 2016. Denne kategoris relative andel af det samlede budget er imidlertid forøget fra $36,0 \%$ i budget 2011 til 37,4\% i budget 2016.

Det samlede budget for Budgetkategori 3, institutioner, er reduceret med 12\% fra budget 2011 til budget 2016. Kategorien har i perioden udgjort en ret konstant andel af det samlede budget for Ministerrådet: mellem 40-43\%: 41,5\% i budget 2011 og 40,1\% i budget 2016. Dette dækker dog over betydelige udsving i budgetterne for de enkelte institutioner. Ved omregning af institutionernes budgetter til 2016-prisniveau i værtslandets valuta, kan det konstateres, at Nordens Hus på

Færøerne, Nordens Institut på Grønland og Nordens Institut på Åland alle har fået reduceret deres budgetter med 7-9\% i 2016 i forhold til 2008. Derimod har Nordens Hus i Reykjavik tilsyneladende fået forøget sit budget med $42 \%$, hvilket dog i høj grad skyldes valutakursændringer i perioden, idet ændringen opgjort i DKK i faste priser kun udgør 5,4\%. Blandt de øvrige institutioner har Nordisk Genressource Center (NordGen) fået øget sit budget med 25\% og Nordisk

Energiforskning med 9\% fra 2008 til 2016, mens eksempelvis budgetterne til NordForsk og Nordisk Institution for Videreuddannelse på Arbejdsmiljøområdet (NIVA) er reduceret med henholdsvis 7\% og 13\%. Nordisk Center for Regional Udvikling (NordRegio) har fastholdt sit budget på et stort set uændret niveau, idet budgettet i 2016 i faste priser udgør 98\% af budget 2008.

Budgetkategori 4, Organisationsbidrag, har i perioden 2011-2016 udgjort et nogenlunde konstant beløb i faste priser og en ensartet andel af budgettet: omkring $2 \%$. I budget 2016 er andelen dog øget til 2,8\%. Dette skyldes etablering af en budgetpost til prioriteret virksomhed under Kulturministrenes område med et budget på 2,7 millioner DKK, bidrag til Nordisk Sommeruniversitet på 1,2 millioner DKK, samt at den tidligere institution, Nordisk Informationscenter for Medie- og Kommunikationsforskning (NORDICOM) fra og med budget 2016 er et samarbejdsorgan og budgetmæssigt indgår i kategori 4.

Den relativt større reduktion i Ministerrådenes projektmidler (budgetkategori 1) i forhold til midler afsat til mere permanente aktiviteter (budgetkategori 2, 3 og 4) betyder formentlig en mindre fleksibilitet til, at Ministerrådene kan igangsætte initiativer som svar på aktuelle politiske behov. Dermed kommer det mere langsigtede arbejde med programmer, samarbejdsorganer og institutioner til at fylde mere. På den anden side gør denne mere langsigtede fastlæggelse af aktiviteterne sammen med den større vægt på, at prioriteringerne for kategori 1 fastlægges under udarbejdelse af budgetforslaget, at den politiske indsigt fra Nordisk Råds side formentlig er blevet øget, da en større andel af budgetmidlerne dermed er allokeret allerede i Generalsekretærens budgetforslag.

\section{Konsekvenser af omprioriteringer og nedskæringer}

Konsekvenserne af ændringerne i Ministerrådets budget har blandt andre været:

- Etableringen af de centrale puljer har ført til større synlighed af de prioriterede indsatser, mere tværsektorielt samarbejde og nye samarbejdsformer samt en betydelig multiplikatoreffekt med hensyn til at tiltrække medfinansiering til projekterne. 
- Nedskæringerne i budgetterne har påvirket aktiviteten på de berørte omåder og har blandt andet reduceret Ministerrådenes projektmidler til aktuelle politiske tiltag, og - for visse samarbejdsorganer - betydet en svagere nordisk profil

- $\quad$ Endringerne i budgettet har også betydet en øget fokusering og prioritering af Ministerrådenes aktiviteter og en skærpet opmærksomhed på styringen af projekter og på mulighederne for proaktivt at tiltrække finansiering, også fra andre kilder.

\section{Evalueringer af de centrale puljer i budgettet}

Der foreligger på nuværende tidspunkt kun evalueringer af projekterne under Globaliseringsinitiativet. En evaluering af initiativerne Grøn Vækst og Holdbar Nordisk Velfærd færdiggøres i løbet af februar 2016 og indgår derfor ikke i denne rapport. Der foreligger heller ikke på nuværende tidspunkt evalueringer af formandskabsdelen af Prioriteringsbudgettet.

Resultaterne af Globaliseringsinitiativet er sammenfattet i en rapport fra Nordisk Ministerråds Sekretariat fra 2012. I følge rapporten har Globaliseringsinitiativet ført til et styrket, mere modent og fokuseret nordisk samarbejde og har hjulpet de nordiske Samarbejdsministre til at prioritere bedre og til at øge samarbejdet mellem forskellige sektorer. Rapporten fremhæver, at Globaliseringsinitiativet først og fremmest har haft betydning på følgende fire områder: 1) Profilering af Norden som en foregangsregion, 2) Øget tværsektorielt samarbejde i Nordisk Ministerråd, 3) Nye samarbejdsformer også i de berørte miljøer i de nordiske lande, 4) Medfinansiering har medvirket til, at effekten af de nordiske midler er blevet større.

En del af projekterne under Globaliseringsinitiativet er blevet evalueret af eksterne evaluatorer, herunder Topforskningsinitiativet, som var det største af Globaliseringsinitiativerne fra 2008, og som blev gennemført i årene 2009-2012 med et budget på ca. 28 millioner DKK (2016-priser) fra puljen afsat til Globaliseringsinitiativet. I rapporten fra 2012 nævnes det, at de i alt 33 forskningsprojekter, som blev finansieret af Topforskningsinitiativet, samlet set havde genereret et budget på 700 millioner NOK. I den eksterne evaluering af Topforskningsinitiativet, foretaget af Damvad i 2014, nævnes det, at initiativet, trods en turbulent og vanskelig start, har levet op til sine oprindelige målsætninger om at skabe øget synlighed og øget samarbejde mellem forskningsinstitutioner i de nordiske lande.

\section{Interviewpersoner om de centrale puljer}

\section{Institutioner}

Tre af de interviewede institutioner har været direkte involveret i projekter under Globaliseringsinitiativet og Grøn Vækst: Nordisk Innovation, NordForsk og Nordisk Velfærdscenter. Generelt ser tre institutioner meget positivt på deres medvirken i projekterne under de centrale puljer, fordi projekterne har skabt nye samarbejdsformer med nye samarbejdspartnere i Norden. Dette stemmer overens med, hvad der er nævnt i de eksterne evalueringer af Globaliseringsinitiativerne.

En enkelt institution bemærker i sin besvarelse, at den ikke i samme omfang som ved udformningen af Globaliseringsinitiativer har været involveret i drøftelser om initiativer under Prioriteringsbudgettet, og bemærker, at projekterne på institutionens område under 
Prioriteringsbudgettet i højere grad synes at være bestemt af nationale interesser fremfor af nordiske.

\section{Samarbejdsorganer}

Ingen af de tre samarbejdsorganer, som har besvaret interviewspørgsmål, har været involveret i projekter under de centrale puljer.

\section{Nordisk Ministerråds Sekretariat}

Blandt de interviewede i Nordisk Ministerråds Sekretariat har følgende områder været involveret i projekter under de centrale puljer: Ministerrådet for Social- og Helsepolitik (MR-S), Ministerrådet for Uddannelse og Forskning (MR-U), Ministerrådet for Fiskeri, Havbrug, Levnedsmidler, Jordbrug og Skovbrug (MR-FJLS) og Ministerrådet for Erhvervs-, Energi og Regionalpolitik (MR-NER). På MR-FJLS området nævnes det, at man som konsekvens af tidligere nedskæringer har arbejdet proaktivt for at tiltrække nye midler til prioriterede initiativer, og derfor har kunnet komme med forslag til de forskellige puljer og initiativer og således dels har medvirket til at sætte dagsordnen, dels har opnået finansiering. På MR-NER området har puljerne, udover nedskæringer, ført til en skærpet styring af projekter, blandt andet med hensyn til tidsafgrænsning af projekter. For MR-U og MR-S fremhæves det, at programmet Holdbar Nordisk Velfærd har ført til et tæt samarbejde på de to Ministerråds områder.

\section{Parlamentarikere}

Kun en af de fem parlamentarikere, som har besvaret interviewspørgsmålene, forholder sig direkte til de centrale puljer. Den pågældende nævner, at etableringen af disse har medført, at Ministerrådet råder over store og udefinerede puljer, hvor Nordisk Råd kun har begrænset indflydelse på, hvad midlerne anvendes til. Samme person nævner dog også, at selvom Nordisk Råd har fået mindre indflydelse, så har puljerne den fordel, at Ministerrådet og formandskabslandet har fået større muligheder for at påvirke det nordiske samarbejde. Det fokus på enkelte sektorer, som er opnået gennem de større udredninger, som eksempelvis Bo Könbergs rapport som del af initiativet Holdbar Nordisk Velfærd, fremhæves som det hidtil bedste ved de seneste års ændringer.

\section{Interviewpersoner om nedskæringer}

\section{Institutioner}

De fire interviewede institutioner har generelt haft gode muligheder for at tilpasse sig budgetændringerne, ved enten at opnå øget national medfinansiering eller ved at reducere størrelsen af budgettet.

Institutionerne oplyser, at de har haft løbende kontakt med Nordisk Ministerråds Sekretariat i processen om nedskæringer og omprioriteringer.

En enkelt institution, Nordisk Innovation, har pga. overflytning af et samarbejdsområde (Grænsehindringsarbejdet) til Sekretariatet kunnet afsætte flere midler til samarbejde på andre 
områder. Øvrige interviewede institutioner har ikke oplevet ændringer i arbejdsfordelingen mellem institutionen og Ministerrådets sekretariat.

\section{Samarbejdsorganer}

Tre samarbejdsorganer på forskningsområdet, som alle har oplevet nedskæringer på 20\% fra 2013 til 2014, er blevet interviewet. For alle tre har nedskæringerne betydet reduktion i antal ansatte, og at samarbejdsorganernes nordiske profil er blevet svækket. De tre samarbejdsorganer har $\mathrm{i}$ forskellig grad haft mulighed for at erstatte den nordiske finansiering med national finansiering eller EU-finansiering af projekter. Dette gælder eksempelvis Nordisk Vulkanologisk Institut (NordVulk), som i en periode har fået øgede forskningsmidler til sin vulkanologiske forskning efter vulkanen Eyjafjallajökull's udbrud i 2010. Disse muligheder vurderes dog som udtømt i de nyeste EUprogrammer på området. Et af samarbejdsorganerne, Nordisk Institut for Asienstudier (NIAS), ser mulighederne for at opnå anden finansiering for begrænsede.

\section{Nordisk Ministerråds Sekretariat}

Interviewpersonerne fra Nordisk Ministerråds Sekretariat understreger, at man ved nedskæringerne i de seneste år har foretaget en prioritering mellem forskellige samarbejdsområder. For eksempel har man på Kulturministrenes (MR-K) område taget udgangspunkt i hvilke områder, som man ønskede at friholde for besparelser, og derefter foretaget en prioriteret besparelse på blandt andet Nordisk Journalistcenter (NJC) i budget 2014 og Nordisk Dataspilprogram i budget 2015. På Ministerrådet for Fiskeri, Havbrug, Levnedsmidler, Jordbrug og Skovbrug's (MR-FJLS) område har en tilsvarende prioriteringsproces ført til nedskæring af budgettet til Ny Nordisk Mad-programmet, ligesom der eksempelvis på området for Erhvervspolitik (under Ministerrådet for Erhvervs-, Energi- og Regionalpolitik) blev prioriteret, så hele besparelsen blev båret af Nordisk Innovation. På Internationalt Samarbejde (under Samarbejdsministrene) har man beskåret forskellige projektpuljer såsom Østersøsamarbejde og Arktisk Samarbejdsprogram, og som følge af en negativ politisk udvikling mellem Rusland og Nordisk Ministerråd er der derudover blevet gennemført en større strukturel nedskæring på både kontorer og aktiviteter i Ruslandssamarbejdet i budget 2016. På Ministerrådet for Social og Helsepolitik's (MR-S) område har man taget en stor del af besparelserne fra sektorens projektmidler, men friholdt den prioriterede indsats "Inklusion af udsatte unge i arbejdsliv og uddannelse", og derudover - i budget 2014 og budget 2015 - fordelt besparelsen ligeligt på sektorens budgetposter. For Ministerrådet for Uddannelse og Forskning (MR-U) anvendte man i årene 2008-2011 pro-rata besparelser, mens man i budget 2014 og budget 2015 har prioriteret mellem sektorens budgetposter. Dette betyder, at eksempelvis samarbejdsorganerne er blevet pålagt en besparelse på 20\% i budget 2014, og at MR-Us dispositionsmidler er reduceret med 55\% fra budget 2014 til budget 2016 .

\section{Parlamentarikere}

De fem parlamentarikere, som har besvaret interviewspørgsmålene, har forskellige holdninger til de gennemførte omprioriteringer og nedskæringer i Nordisk Ministerråds budget. To respondenter har anført, at det er tydeligt, at nedskæringerne har påvirket aktiviteten, og den ene nævner, at dette i nogle tilfælde har vanskeliggjort institutionernes arbejde. I den sammenhæng er der behov for en mere klar prioritering, så gamle aktiviteter afsluttes, når nye sættes igang. De øvrige tre 
respondenter ser enten ikke negative effekter af ændringerne i budgettet eller har ikke udtrykt en holdning til dette spørgsmål.

\section{Nordisk Råd og Nordisk Ministerråds budgetproces}

Nordisk Råds rolle i Nordisk Ministerråds budgetproces er karakteriseret ved:

- At Nordisk Råd reagerer på Generalsekretærens budgetforslag fremfor proaktivt at komme med forslag til prioriteringer, før budgetanvisningerne udarbejdes.

- At Nordisk Råd fremkommer med mange og forskelligartede forslag til budgetforslaget, hvoraf særligt de helt konkrete ændringsforslag i stort omgang bliver implementeret i det endelige budget. De gennemførte ændringsforslag udgør dog typisk mindre end 1\% af Ministerrådets budget.

- At Nordisk Råd har en reel indflydelse på det endelige budget, men at der inden for rammerne af samarbejdet er yderligere muligheder, som kan imødekomme ønsket fra Rådets medlemmer om en styrket indflydelse.

\section{Nordisk Råds rolle i budgetprocessen}

I følge Helsingforsaftalens artikel 64 skal Nordisk Ministerråd "fremlægge sit forslag til budget for Nordisk Råd til udtalelse. Nordisk Råd kan foreslå ændrede prioriteringer inden for den af Ministerrådet angivne finansielle ramme. Hvis ikke særlige omstændigheder kan anføres, skal Ministerrådet følge Rådets anbefalinger, når det gælder budgetdispositioner inden for den angivne finansielle ramme."

I den nuværende budgetproces har Nordisk Råd og Nordisk Ministerråd typisk tre fælles drøftelser om budgettet før dets vedtagelse: Første drøftelse sker mellem formanden for

Samarbejdsministrene og Nordisk Råds Budgetgruppe/Præsidiet forud for samarbejdsministrenes beslutning om budgetanvisninger (januar/februar). Næste møde er ved oversendelse af Generalsekretærens budgetforslag til Nordisk Råd i juni, hvor Nordisk Ministerråd tilbyder at gennemgå forslaget for parlamentarikere og embedsmænd, samtidigt med at budgetforslaget oversendes til høring i landene. Tredje møde er i september, hvor de endelige budgetforhandlinger mellem Råd og Ministerråd afsluttes. I denne budgetproces er Nordisk Råds rolle først og fremmest at reagere på Generalsekretærens budgetforslag fremfor proaktivt at fremsætte egne forslag.

I rapporten om Ministerrådets moderniseringsarbejde "Nyt Norden. Afrapportering på generalsekretærens moderniseringsforslag" nævnes det, at Ministerrådet ønsker at indføre et møde i efteråret to år før budgetåret med henblik på at drøfte næste budgetårs prioritering, før budgetanvisningerne bliver udarbejdet, eksempelvis et møde om budgetprioriteringerne for $2018 \mathrm{i}$ efteråret 2016.

Budgetarbejdet er fra 2015 blevet en del af Præsidiets arbejde, idet Præsidiets budgetgruppe er blevet nedlagt. Det er dog som hidtil partigruppernes budgetordførere, som er Nordisk Råds forhandlingspart i budgetforhandlingerne med Nordisk Ministerråd. 
Med Nordisk Ministerråds ønske om en øget inddragelse af Nordisk Råd i budgetprocessen og med opprioriteringen af budgetarbejdet i Nordisk Råd Præsidium, synes der at være de nødvendige forudsætninger for, at Rådet kan få en styrket rolle i budgetprocessen.

\section{Nordisk Råds input til budgetprocessen 2008-2016}

Nordisk Råd har hvert år i perioden haft forslag til ændringer i Nordisk Ministerråds budget. Nordisk Råds forslag er blevet præsenteret til Ministerrådet i august efter modtagelse af Generalsekretærens budgetforslag i juni med henblik på forhandlinger i september.

Nordisk Råds forslag til budgettet kan opdeles i fire typer forslag:

1. Forslag til konkrete ændringer i budgettet med et specifikt beløb angivet. Dette kan være om tildeling af midler til særligt formål eller reduktion af en foreslået besparelse. Eksempelvis at der afsættes 1 million DKK i budget 2016 til Nordisk Journalistcenter (NJC).

2. Ønske om at et givent område prioriteres i årets budget uden angivelse af beløb. Eksempelvis, at det nordiske samarbejde indenfor Erhvervspolitik i budget 2016 skal fokusere på innovative, digitale løsninger som grundlag for produktion i Norden.

3. Konkrete politiske ønsker, som ikke nødvendigvis har med budgettet at gøre, men som kan have budgetmæssige konsekvenser. Eksempelvis, at satsningen på bioøkonomi er en vigtig del af arbejdet med grøn økonomisk vækst og holdbarhed (budget 2015), at transport skal indgå i det nye energipolitiske handlingsprogram (budget 2014).

4. Strukturelle forslag til selve budgetprocessen, eksempelvis at inddrage Nordisk Råd tidligere i budgetprocessen (budget 2015).

Antallet af forslag fra Nordisk Råd har i perioden været mellem 5 til budget 2011 og 30 til budget 2015. Antallet af forslag er generelt øget gennem perioden. En del af de konkrete ændringsforslag (type 1 ovenfor) er ønske om øremærkning af midler til et bestemt formål indenfor en given budgetpost. Andre type 1 forslag er forslag til opprioritering af et område, hvor der ikke altid er blevet foreslået finansiering. For type 2 forslagene er der generelt ikke forslag til finansiering af de ønskede prioriteringer. Type 3 forslagene knytter sig formentlig i nogen grad til rekommandationer fra Nordisk Råd, hvor man også ønsker at fremhæve forslaget i forbindelse med budgetforhandlingerne. De strukturelle forslag (type 4) har som sådan ikke at gøre med det konkrete budget, men er henstillinger til Nordisk Ministerråd om at ændre og forbedre budgetprocessen.

\section{Nordisk Råds indflydelse på Nordisk Ministerråds budget}

Generelt er mange af Nordisk Råds forslag til konkrete, mindre ændringer i budgettet (type 1) blevet imødekommet af Nordisk Ministerråd. Det gælder eksempelvis tildeling af 1 million DKK til Nordisk Journalistcenter (NJC) i budgetterne for 2014, 2015 og 2016 eller øremærkning af midler til Nordisk Biblioteksuge i budgetterne for 2009 og 2010. Størrelsesordenen af budgetændringerne på baggrund af Nordisk Råds forslag er typisk mellem 3 og 6 millioner DKK, svarende til mindre end $1 \%$ af de årlige budgetter for Ministerrådet.

De forslag, som omhandler prioritering af et særligt område i årets budget (type 2) er i høj grad imødekommet, selvom der sjældent er forslag om finansiering. Forslagene, som ikke nødvendigvis 
har med årets budget at gøre (type 3) er i varierende grad blevet imødekommet. Eksempelvis er forslaget om en udredning vedrørende Kulturkontakt Nord og Nordisk Kultur Fond fremsat til budget 2014 imødekommet, mens et forslag om nedlæggelse af to af Ministerrådets baltiske kontorer til budget 2015 blev afvist.

Nordisk Råd har i den undersøgte periode fremsat nogle enkelte forslag til selve budgetprocessen (type 4). I forhandlingerne om budget 2011 ønskede Rådet mere transparens i budgetprocessen, hvilket blev imødekommet med henvisning til, at Ministerrådet havde foretaget en ændring af budgetkategorierne. Igen til forhandlingerne om budget 2015 havde Nordisk Råd forskellige forslag til processen: et ønske om at friholde borgerrelaterede aktiviteter og institutioner for besparelse, et forslag om dialog med Nordisk Råd om Ministerrådets uforbrugte midler samt et forslag om tidligere inddragelse af Nordisk Råd i budgetprocessen. Af disse tre forslag blev kun forslaget om tidligere inddragelse af Rådet i budgetprocessen imødekommet.

\section{Interviewpersoner om Nordisk Råds rolle i budgetprocessen}

\section{Nordisk Ministerråd}

Flere af de interviewede samarbejdsorganer oplyser, at de har haft kontakt til og drøftelser med medlemmer af Nordisk Råd i forbindelse med de seneste års nedskæringer, dog uden at det tilsyneladende har påvirket den endelige beslutning. De interviewede institutioner oplyser, at de kun har haft kontakter til Nordisk Ministerråds Sekretariat i budgetprocessen og altså ikke til Nordisk Råd. Generelt har de interviewede institutioner og samarbejdsorganer ikke viden om, hvorvidt budgetforhandlingerne mellem Nordisk Råd og Nordisk Ministerråd har påvirket beslutninger om deres budgetter.

Fra Nordisk Ministerråds Sekretariat nævnes flere eksempler på, at budgetforhandlingerne har påvirket udformningen af det endelige budget i forhold til forslaget fra Generalsekretæren. Eksempelvis har budgetforhandlingerne ført til opprioritering af Ny Nordisk Mad-programmet, Nordisk Journalistcenter, Nordisk Sommeruniversitet, opfølgning af anbefalingerne fra Bo Könbergs rapport og en fornyet indsats mod menneskehandel.

\section{Nordisk Råd}

Fire af de fem interviewede parlamentarikere mener, at Nordisk Råds indflydelse i budgetforhandlingerne har været meget begrænset eller helt ubetydelig. To af dem nævner dog Nordisk Sommeruniversitet og Nordisk Journalistcenter som positive eksempler på, at Nordisk Råd har kunnet påvirke det endelige budget.

Meningerne er delte med hensyn til, om Nordisk Råd bør få en større rolle i budgetprocessen. Én parlamentariker mener, at Nordisk Råds mulighed for at påvirke budgettet er så begrænset, at det vil være bedre helt at afstå fra dette. Andre mener, at Nordisk Råd bør have en større rolle, og at Nordisk Ministerråd bør tage mere hensyn til Rådets forslag. I den sammenhæng nævner en af parlamentarikerne, at både udvalg og partigrupper bør have en meget større rolle. For eksempel at udvalgene i Nordisk Råd skal behandle de sektorer, der hører til udvalget, og på den baggrund stille ændringsforslag, samt at også Præsidiet bør bruge mere tid til processen sammen med ministre og embedsmænd fra Nordisk Ministerråd. Det nævnes dog også, at dette vil kræve en styrkelse af det politiske arbejde i Nordisk Råd, da medlemmerne i dag ikke har tid nok til arbejdet. 


\section{En styrket rolle for Nordisk Råd i budgetprocessen?}

Nordisk Råds forslag til Nordisk Ministerråds budget bærer generelt præg af at være reaktioner på Generalsekretærens budgetforslag og kun i mindre grad udtryk for, at Nordisk Råd $\mathrm{i}$ budgetprocessen fremkommer med sine konkrete forslag til prioriteringer og ønsker til udviklingen af det nordiske samarbejde.

I lyset af at en del af Nordisk Råds forslag bliver implementeret i det endelige budget for Nordisk Ministerråd, kunne Nordisk Råd formentlig i højere grad påvirke budgetprocessen, hvis man agerede proaktivt og fremkom med sine forslag før udarbejdelsen af budgetanvisningerne, jævnfør også rapporten om Ministerrådets moderniseringsarbejde.

Nordisk Råds forslag vil formentlig kunne få en større tyngde, hvis der eksempelvis foreslås finansiering af forslagene eller de støttes af en udredning om den pågældende problemstilling eller andet baggrundsmateriale. Det sidste gælder særligt de mere strukturelle forslag om op- eller nedprioritering af et område eller de tilfælde, hvor et forslag gentagne gange er blevet afvist $\mathrm{i}$ budgetforhandlingerne med Ministerrådet.

Nordisk Råds input til budgetprocessen kan formentlig styrkes ved, at Rådet tidligere i processen drøfter sine forslag til prioriteringer i budgettet. Dette kan ske ved, at Nordisk Råds udvalg, partigrupper samt Præsidiet i efteråret to år før budgetåret drøfter prioriteringer for budgettet. Eksempelvis at ønsker til budget 2018 drøftes i efteråret 2016, så et gennemarbejdet forslag til prioriteringer fra Nordisk Råd kan blive drøftet med Samarbejdsministrene, før budgetanvisningerne for Ministerrådets budget udarbejdes af Sekretariatet og godkendes af Samarbejdsministrene.

Derudover kan Nordisk Råds udvalg i højere grad spille en aktiv rolle ved, at hvert udvalg behandler de sektorer, der hører til udvalget. Dette kan være dels som et indspil til prioriteringerne for budgettet, dels som ændringsforslag til Generalsekretærens budgetforslag. Såfremt udvalgene skal have en mere aktiv rolle i budgetprocessen, bør kapaciteten i Nordisk Råds Sekretariat formentlig styrkes.

I præsentationen af forslagene fra Nordisk Råd, kunne man endvidere overveje at opdele forslagene i forskellige typer: konkrete henholdsvis strukturelle forslag. Dette ville bidrage til større overskuelighed samt formentlig også forbedre Nordisk Råds proces med at prioritere forslagene.

Endvidere bør Nordisk Råd løbende have en dialog med Ministerrådet om forslag og ønsker til prioritering.

\section{Konklusion og anbefalinger}

Udviklingen i Nordisk Ministerråds budget i 2008-2016 har været karakteriseret ved tre væsentlige træk: Etablering af centrale puljer på 7-8 \% af Ministerrådets budget, nedskæringer i den samlede ramme for Ministerrådets budget med $9 \%$ i perioden samt forskydning mellem andelen af projektmidler og midler til mere permanente aktiviteter i Ministerrådets budget. Nedskæringerne er i høj grad gennemført som gradvise pro rata beskæringer af de fleste budgetposter. Hvis det igen skulle blive aktuelt at foretage nedskæringer i budgettet, bør det overvejes at prioritere nedskæringerne, det vil sige overveje at friholde nogle budgetposter fra nedskæringer og samtidig nedlægge andre aktiviteter og samarbejdsområder. Dette har man eksempelvis været gjort på 
Kulturministrenes område, hvor man i budget 2014 og budget 2015 friholdt nogle områder og foretog prioriterede besparelser på Nordisk Journalistcenter og Dataspilsprogrammet. Samme tilgang kunne også have været relevant i forhold til bevillingerne til de mindre samarbejdsorganer på forskningsområdet, som oplevede markante nedskæringer fra budget 2013 til budget 2014 .

ÆEndringerne i Ministerrådets budget har haft en klar påvirkning af aktiviteten på de berørte omåder, blandt andet er Ministerrådenes projektmidler til aktuelle politiske tiltag reduceret, og på nogle områder har nedskæringerne ført til en svagere nordisk profil. På den anden side har etableringen af de centrale puljer medført større synlighed af de prioriterede indsatser, mere tværsektorielt samarbejde og nye samarbejdsformer. Derudover har ændringerne i budgettet også betydet en øget fokusering og prioritering af Ministerrådenes aktiviteter og en skærpet opmærksomhed på styringen af projekter og på mulighederne for at opnå medfinansiering fra andre kilder. Hvorvidt projekterne i Prioriteringsbudgettet på nogle områder i højere grad er udtryk for nationale prioriteringer end projekterne under Globaliseringsinitiativet er ikke belyst i denne analyse, men er et spørgsmål, som kan belyses i en evaluering af Prioriteringsbudgettet.

Nordisk Råds rolle i Nordisk Ministerråds budgetproces er karakteriseret ved, at Nordisk Råd reagerer på Generalsekretærens budgetforslag fremfor, at man proaktivt kommer med forslag, før budgetanvisningerne udarbejdes. Nordisk Råds forslag er mange og forskelligartede, og især de helt konkrete ændringsforslag bliver i stort omgang inkluderet i det endelige budget. Nordisk Råd har således en reel indflydelse på det endelige budget, men der er blandt Rådets medlemmer er et ønske om en yderligere styrkelse af indflydelsen.

På baggrund af analysen af Nordisk Råds rolle i Nordisk Ministerråds budgetproces, anbefales følgende:

1. Nordisk Råd bør have en mere proaktiv tilgang til budgetprocessen.

2. Nordisk Råds udvalg og partigrupper bør drøfte prioriteringerne og udarbejde forslag til Præsidiets drøftelse med Ministerrådet, før budgetanvisningerne udarbejdes.

3. Nordisk Råd bør overveje forslag til finansiering af forslag i form af omprioriteringer i budgettet.

4. Nordisk Råd bør i visse tilfælde udarbejde en udredning eller andet baggrundsmateriale for at støtte sine forslag.

5. Nordisk Råds udvalg bør have en aktiv rolle i behandlingen af Generalsekretærens budgetforslag for de tilhørende sektorer.

6. Nordisk Råd bør overveje at opdele sine forslag til konkrete og mere strukturelle forslag.

7. Nordisk Råd bør have en løbende dialog med Ministerrådet om sine forslag og ønsker til prioriteringer.

8. Nordisk Råd og Nordisk Ministerråd bør ved eventuelle fremtidige nedskæringer se på mulighederne for at foretage prioriterede nedskæringer på de forskellige Ministerråds områder fremfor pro rata nedskæringer.

9. Nordisk Råd bør overveje at styrke Sekretariatets kapacitet i forhold til budgetarbejdet, særligt i forhold til udarbejdelse af baggrundsmateriale (anbefaling 4) og udvalgenes rolle i budgetarbejdet (anbefaling 5). 


\section{Bilag 1: Interviewspørgsmål}

Spørgsmål sendt til Nordisk Ministerråds Sekretariat, institutioner og samarbejdsorganer:

1. Hvilke af sektorens/institutionens/samarbejdsorganets aktiviteter er blevet påvirket af de seneste års omprioriteringer og nedskæringer i budgettet? Hvordan blev aktiviteterne valgt?

2. Har omprioriteringer/nedskæringer ført til en ændring i fordelingen af opgaver mellem sekretariat/arbejdsgrupper og sektorens institutioner/samarbejdsorganer? Hvilke konsekvenser har dette haft?

3. Har man fra embedsmandskomite/Ministerråd/institutionens/samarbejdsorganets side forsøgt at påvirke beslutningen om nedskæringer? Hvordan?

4. Har budgetforhandlingerne med Nordisk Råd haft indvirken på besparelserne eller på anden måde påvirket udformningen af det endelige budget i forhold til forslaget fra Generalsekretæren?

5. Har sektoren/institutionen/samarbejdsorganet kunnet finde nye midler, så aktiviteterne fortsat kunne gennemføres? Eller så de kunne gennemføres på en anden måde?

6. Har sektoren/institutionen/samarbejdsorganet fået/haft ansvar for projekter under prioriteringsbudgettet, grøn vækst eller globalisering? Hvordan har dette påvirket sektorens/ institutionens/samarbejdsorganets arbejde?

Spørgsmål sendt til Nordisk Råds medlemmer og Sekretariat:

1. Hvordan ser du, at de seneste års omprioriteringer og nedskæringer i Nordisk Ministerråds budget har påvirket Ministerrådets aktiviteter?

2. Hvordan ser du Nordisk Råds rolle i Nordisk Ministerråds budgetproces?

3. Hvad kan der gøres for at styrke Nordisk Råds rolle i Nordisk Ministerråds budgetproces?

4. Har budgetforhandlingerne mellem Nordisk Råd og Nordisk Ministerråd haft indvirken på besparelserne eller på anden måde påvirket udformningen af Nordisk Ministerråds endelige budget i forhold til forslaget fra Generalsekretæren? 


\section{Bilag 2: Interviewede personer og organisationer}

Institutioner:

Nordisk Innovation: Administrationschef Heikki Uusi-Honko

Nordisk Center for Helse og Velfærd, NVC: Administrationschef Jacob Boëthius

NordForsk: Organisationschef Harald Botha

Nordens Hus på Færøerne: Direktør Sif Gunnarsdóttir

Samarbejdsorganer:

Nordisk Institut for Teoretisk Fysik, NORDITA: Direktør Konstantin Zarembo

Nordisk Institut for Asien Studier, NIAS: Direktør Geir Helgesen

Nordisk Vulkanologisk Institut, NordVulk: Direktør Rikke Pedersen

Nordisk Ministerråds Sekretariat:

Stabschef Kenneth Broman vedrørende Internationalt samarbejde

Afdelingschef Mikael Höysti vedrørende MR-FJLS og MR-K

Afdelingschef Annika Rosing vedrørende MR-NER

Afdelingschef Anders Geertsen vedrørende MR-S og MR-U

Nordisk Råd:

Penilla Günther

Annette Lind

Per Olaf Lundteigen

Sonja Mandt

Michael Tetzschner

Nordisk Råds Sekretariat:

Møde med Tina Bostrup, Tryggvi Felixson, Jenny Pentler, Bente Øxseth. 
Effekten af budgetnedskæringer i Nordisk Ministerråd

\section{Bilag 3: Anvendte materialer}

Helsingforsaftalen

Hur blev resultatet av Globaliseringsinitiativet: En sammanställning af globaliseringsinitiativets effekter, Nordisk Ministerråd, 2012

Final Report from the Ongoing Evaluation of the Top-Level Research Initiative, DAMVAD, 2014

The Final Report from the Ongoing Evaluation of the Top-Level Research Initiative, Executive Summary, DAMVAD, 2014

Nyt Norden: Afrapportering på generalsekretærens moderniseringsopdrag, Nordisk Ministerråd. 2014

Mødematerialer fra møder i Nordisk Råds Præsidiums Budgetgruppe

Nordisk Råds Præsidiums betænkninger over Nordisk Ministerråds budgetter 2009-2016 


\section{Bilag 4: Liste over anvendte forkortelser}

MInisterråd:

MR-A: Nordisk Ministerråd for Arbejdsliv

MR-NER: Nordisk Ministerråd for Erhvervs- Energi og Regionalpolitik.

MR-FJLS: Nordisk Ministerråd for Fiskeri, Havbrug, Levnedsmidler, Jordbrug og Skovbrug

MR-JÄM: Nordisk Ministerråd for Ligestilling

MR-K: Nordisk Ministerråd for Kultur

MR-LAG: Nordisk Ministerråd for Lovsamarbejde

MR-M: Nordisk Ministerråd for Miljø

MR-S: Nordisk Ministerråd for Social- og Helsepolitik

MR-U: Nordisk Ministerråd for Uddannelse og Forskning

MR-FINANS: Nordisk Ministerråd for Økonomi og Finanspolitik

MR-SAM: Samarbejdsministrene

Institutioner og samarbejdsorganer:

NHV: Nordic School of Public Health

NIAS: Nordisk Institut for Asienstudier NOPEF: Nordisk Projekteksport Fond

NJC: Nordisk Journalistcenter

NordGen: Nordisk Genressource Center

NORDICOM: Nordisk Informationscenter for Medie og Kommunikationsforskning

NORDITA: Nordisk Institut for Teoretisk Fysik

NordVulk: Nordisk Vulkanologisk Institut 